DOI: $10.14746 /$ por.2018.1.7

\title{
ODA O URNIE GRECKIEJ I MARMUR- -BIAEY W KONTEKŚCIE POGLĄDÓW ESTETYCZNYCH JOHNA KEATSA I CYPRIANA KAMILA NORWIDA
}

\author{
Edyta Ż́reK-HoROdYsKA ${ }^{1}$ \\ (Uniwersytet Jagielloński)
}

Słowa kluczowe: Cyprian Kamil Norwid, John Keats, estetyka, romantyzm, oda

Keywords: Cyprian Kamil Norwid, John Keats, aesthetics, romanticism, ode

\begin{abstract}
Abstrakt: Edyta Żyrek-Horodyska, ODA O URNIE GRECKIEJ I MARMUR-BIAEY W KONTEKŚCIE POGLĄDÓW ESTETYCZNYCH JOHNA KEATSA I CYPRIANA KAMILA NORWIDA. „PORÓWNANIA" 1 (22), 2018. T. XXII, S. 127-143. ISSN 1733-165X. Głównym celem niniejszego artykułu jest komparatystyczne spojrzenie na twórczość Cypriana Kamila Norwida i Johna Keatsa. Przedmiotem analiz są dwa wiersze: Marmur-biały oraz Oda o urnie greckiej, które mogą być odczytywane w kontekście poglądów estetycznych obu romantycznych twórców. Szczególną uwagę zwracam przede wszystkim na stosunek przedstawicieli drugiej generacji romantycznej do tradycji grecko-rzymskiej. Ponadto interesowała mnie również refleksja obu autorów nad zagadnieniami związanymi ze sztuką i miejscem autora w procesie twórczym.
\end{abstract}

\begin{abstract}
Edyta Żyrek-Horodyska, “ODE ON A GRECIAN URN" AND "MARMUR-BIAŁY” IN THE CONTEXT OF AESTHETIC VIEWS OF JOHN KEATS AND CYPRIAN KAMIL NORWID. "PORÓWNANIA" 1 (22), 2018. Vol. XXII, P. 127-143. ISSN 1733-165X. The main aim of this article is to discuss the poetry of Cyprian Kamil Norwid and John Keats in the comparative perspective. I focused on two poems: Marmur-biaty and Ode on a Grecian urn that can be read in the context of aesthetic views of both romantic artists. I am particularly interested in the attitude of the representatives of the second generation of romantic poets to the Greco-Roman tradition. Moreover, I also focus on the reflection of both authors on issues related to art and the place of the author in the creative process.
\end{abstract}

1 E-mail: edytazyrek@wp.pl 
W swej Autobiografii artystycznej Cyprian Kamil Norwid zanotował, iż urodził się, „kiedy w Grecji umierał Noel Byron” (Norwid 556)². Sformułowanie takiej właśnie myśli, w swym literalnym brzemieniu sprzecznej z wiedzą, jaką przekazują biografowie obu romantyków $w^{3}$, każe się zatrzymać nad sensem Norwidowskiego zapisu i podjąć próbę odczytania w nim znaczeń symbolicznych. Początek lat dwudziestych XIX wieku to w Polsce okres, w którym narodziny polskiego romantyzmu zbiegają się z datą przyjścia na świat drugiej generacji jego twórców. W Anglii natomiast owa "pokoleniowa zmiana warty” nastąpiła już wcześniej. Trzecie dziesięciolecie XIX stulecia przynosi tam nie tylko śmierć ważniejszych twórców, ale także wyraźny schyłek epoki. Rok 1821 jest dla piśmiennictwa obu krajów datą, która w historii literatury zasługuje na miano istotnej: wówczas rodzi się Norwid i umiera inny wielki romantyczny poeta - John Keats. Zgodnie z prawdą historyczną zatem to nie nazwisko Byrona, lecz autora Ody o urnie greckiej mogłoby znaleźć się we wspomnianej już Autobiografii artystycznej polskiego pisarza.

Bezpośrednią inspiracją do podjęcia badań porównawczych nad poglądami estetycznymi Norwida i Keatsa mogą być słowa Ireny Sławińskiej, przekonującej, iż „idea Keatsa z Ody o urnie greckiej [to - E.Ż.H.] idea bliska i Norwidowi, który wie, że «pod dłutem zwieczniają się chwile» (Posąg i obuwie). Twórczy trud chwili zapewnia wieczność dziełu sztuki" (Sławińska 40). Wypowiedź badaczki może być odczytywana jako próba zwrócenia uwagi na dwa istotne elementy. Pierwszym z nich jest kwestia rozumienia i definiowania przez obydwu poetów pojęcia sztuki, drugim natomiast - sposób kreślenia przez nich zależności pomiędzy czasem a dziełem artystycznym, którego cel istnienia wiązać należy z pragnieniem „wymknięcia się przemijalności" (Sławińska 40). Zasygnalizowane przez badaczkę problemy warto potraktować jako asumpt do podjęcia głębszej refleksji ogniskującej się wokół poglądów estetycznych Norwida i Keatsa.

Zauważyć można liczne paralele $w$ sposobie pojmowania sztuki przez drugie pokolenie romantyków polskich i angielskich. Sytuacja, w jakiej znaleźli się ci artyści, była szczególna. Jako spadkobiercy myśli romantycznej wyznaczonej przez Williama Wordswortha z jednej, a Adama Mickiewicza z drugiej strony, definicje piękna tworzyli w odniesieniu do przemyśleń swych wybitnych poprzedników. Mieli przy tym świadomość, iż, „stojąc na ramionach wielkoludów”, winni wykorzystać je, aby spojrzeć dalej i wyżej, żeby wyznaczyć własny kierunek dążeń artystycznych. Celem podjętych przeze mnie w tym szkicu rozważań będzie zestawienie i porównanie dwóch utworów literackich: Ody o urnie greckiej Keatsa oraz Marmuru-biatego Norwida. Liryki te uznać można za skondensowaną wykładnię poglądów estetycznych twórców. Ich odczytanie połączone z lekturą fragmentów listów oraz

2 Fragmenty Marmuru-białego podaję za: Norwid, Cyprian Kamil: Pisma wszystkie. Zebrał, tekst ustalił, wstępem i uwagami krytycznymi opatrzył J.W. Gomulicki. Warszawa: PIW, 1971, w nawiasie wskazując numer wersu.

3 Norwid urodził się w 1821 roku, Byron natomiast zmarł w roku 1824. 
tekstów teoretycznoliterackich romantycznych poetów pozwoli na przedstawienie znamiennych różnic i podobieństw w pojmowaniu piękna przez obu artystów.

\section{Piękno w ujęciu Norwida i Keatsa}

Keats i Norwid wierzyli, że rozumienie XIX-wiecznej sztuki bez poszanowania dorobku myśli i kultury starożytnej uznać należy za niepełne. Przekonanie Norwida, iż „oryginalność jest to sumienność w obliczu źródel” (Norwid 432), patronowało także myśli estetycznej Keatsa, który upominał się o docenienie wpływu tradycji antycznej na kształt sztuki pierwszej połowy XIX stulecia. Obaj autorzy jak wielu ówczesnych artystów - chętnie zwracali się w kierunku kultury starożytnej, podejmując refleksję nad kwestiami estetycznymi, historiograficznymi czy antropologicznymi. Przyczyny tego faktu związane są z ważnymi wydarzeniami historycznymi. Warto wspomnieć tutaj o silnej na początku XIX wieku fascynacji marmurami lorda Elgina (The Elgin Marbles). Podziwianie dzieł sztuki antycznej było wówczas niezwykle modne i owocowało nawet zakładaniem przez Anglików prywatnych galerii. Obecność Keatsa na takich wystawach, gdzie mógł oglądać antyczne urny, jest udokumentowana. Ian Jack zwraca uwagę, iż poeta podziwiał je wraz z swoim przyjacielem, Haydonem, w 1817 roku. Opinia Haydona na ich temat (znana Keatsowi) brzmiała: „I felt as if a divine truth had blazed inwardly upon my mind" (Jack 32). Co znamienne, podobne uczucia towarzyszą podmiotowi lirycznemu w Odzie o urnie greckiej Keatsa.

Twórcą zajmującym w Norwidowskiej refleksji estetycznej poczesne miejsce jest Homer ${ }^{4}$ (Szturc 198-201). Nieprzypadkowo zapewne autor Promethidiona postaci tej poświęcił całą pierwszą strofoidę Marmuru-białego. Jak pisze Zofia Szmydtowa, "Norwid podziwiał u Homera [...] naturalność, podobnie jak w rzeźbie i malarstwie greckim. [...] Wyraźnie wskazuje na to wstęp poprzedzający tłumaczone przez Norwida fragmenty z Odysei ze stycznia 1870. «Homer jest naturalnym [...]. Oto i wszystko [...]»" (Szmydtowa 671). Ustalenia badaczki podkreślające Norwidowską chęć czerpania z antycznych źródeł tradycji warto uzupełnić o wnioski nasuwające się po lekturze Marmuru-białego, gdzie niewidomy twórca Iliady jawi się jako ten, który nauczył Grecję śpiewać. Homer, tworząc, jednocześnie wykonywał pracę. Powiązanie tych dwóch czynności jest częste w myśli Norwida. Prowadzi ono poetę do refleksji nad wiecznością dzieła i częstym zapominaniem o jego twórcy. Odpowiedzią na tę sytuację stało się sformułowanie przez osobę mówiącą w wierszu postulatu, iż Grecja winna wdzięczność śpiewakowi, która - co cieka-

4 Warto zauważyć, iż autor Iliady niezwykle ważne miejsce zajmuje także w twórczości Keatsa. Romantyczny poeta wspomina o greckim artyście w utworach takich jak On First Looking into Chapman's Homer czy To Homer. 
we - ma wyrażać się poprzez „szmer / Fal egejskich, bijących w heksametr o skałę” (w. 5). Za dar godny artysty uznana być może jedynie sztuka doskonała, naturalna, słyszalna (czyli percypowana zmysłowo), stworzona na miarę tej, jaka wyszła spod pióra Homera.

Druga strofoida Marmuru-białego wykazuje znamienny paralelizm budowy $\mathrm{w}$ stosunku do strofoidy pierwszej. Po raz wtóry w tym miejscu postawione zostaje pytanie o los wielkich postaci. Wspomnienie Fidiasza wiąże się (podobnie jak miało to miejsce w przypadku Homera) z przyznaniem artyście roli nauczyciela, który "uczył kibić wyginać dostojnie / I stąpać jako bogi [...]” (w. 8, 9). Tok rozważań dotyczących rzeźbiarza zostaje nagle przerwany przez enumerację imion innych bohaterów. Przywoływani zostają kolejno: Milcjad, Temistokles, Tucydyd, Cynom, Arystyd i Focjon - wybitni mężowie, którzy również dzielą tragiczny los wcześniej wymienionych postaci. Norwid nieprzypadkowo zapewne wspomina te właśnie nazwiska w liryku poświęconym zagadnieniom działalności artystycznej. Wywodząc bowiem wyraz "sztuka” od greckiego techne, miano artysty poeta przyznaje temu, kto posiada określoną umiejętność, zdolność do tworzenia bądź wytwarzania ${ }^{5}$ (Tatarkiewicz 21). Potwierdzenia słuszności powyższej tezy szukać należy w jednej z rozpraw autora Quidama, gdzie czytamy: „inżynieria, lub wyłączniej; sama sztuka wojskowa, jakkolwiek i ta jeszcze [...] jest sztuką" (Norwid 338).

Norwidowskie rozumienie działalności artystycznej kształtowało się pod wpływem starożytnych koncepcji estetycznych, każących widzieć w twórczości rodzaj rzemiosła, umiejętności, którą można posiąść poprzez naukę i praktykę. Zofia Stefanowska $\mathrm{w}$ takim sposobie definiowania sztuki dostrzega cechy wyraźnie ambiwalentne. Opozycję wobec estetyki romantycznej stanowi, w przekonaniu badaczki, Norwidowskie ujęcie „sztuki sprowadzonej na ziemię, skojarzonej z [...] przemysłem”. Jednocześnie jest to jednak "sztuka bardzo romantyczna, absolutyzowana jako wartość nadrzędna i niezależna" (Stefanowska 12). Naturalną wręcz konsekwencją wspomnianej przez Stefanowską absolutyzacji i gloryfikacji działalności artystycznej stać się może marginalizowanie roli artysty. Pytania stawiane przez „ja" liryczne w wierszu Norwida o miejsce pobytu i los najsławniejszych greckich mężów przypominają w swej konstrukcji realizację średniowiecznego toposu $u b i$ sunt. Głównym celem podjęcia przez podmiot mówiący refleksji nad losami artystów i wojowników nie jest jednak zwrócenie uwagi na upływ czasu i schodzenie ze sceny świata poszczególnych ludzkich istnień, a raczej na ich znikanie z ludzkiej pamięci. Dlatego Marmur-biaty Aleksandra Melbechowska-Luty nazywa „historią o wielkich poniżanych i zapomnianych" (Melbechowska-Luty 258). Zdzisław Ła-

5 Jak zauważa Władysław Tatarkiewicz, „techne w Grecji, ars w Rzymie i w średniowieczu, nawet jeszcze w początkach ery nowożytnej, w dobie Oświecenia, znaczyły tyle, co umiejętność, mianowicie - umiejętność zrobienia jakiegoś przedmiotu, domu, posągu, okrętu, łóżka, garnka, odzieży, a ponadto także umiejętność dowodzenia wojskiem, mierzenia pola, przekonywania słuchaczy. Wszystkie te umiejętności były nazywane sztukami" (Tatarkiewicz 21). 
piński z kolei, analizując ten liryk, mówi o wyrażonej w nim „ironii losów wielkich postaci" (Łapiński 114-115). Podobna myśl pojawia się w pracy Włodzimierza Szturca, gdzie wiersz Norwida nazwany zostaje pytaniem "o stan współczesnej Grecji, która zdaje się nie pamiętać swoich Homerów, Sokratesa, Fidiasza i Tucydydesa" (Szturc 193).

Przytoczone wyżej uwagi odnieść można również do Ody o urnie greckiej. Wiersz ten, podobnie jak liryk Norwida, traktuje o idei antycznego piękna, eksponując jednocześnie jego trwałość i nieprzemijalność. Znamienne, że kontemplacji wyjątkowości starożytnej urny towarzyszy zupełne przemilczenie postaci twórcy, którego osoba nie zostaje przywołana w żadnej z pięciu tworzących odę strof. Angielski poeta dokonuje swego rodzaju reinterpretacji Horacjańskiego non omnis moriar, pojmowanego tym razem $w$ kategoriach unieśmiertelnienia nie tyle twórcy, ile artefaktu. Istniejące dzieło w miarę upływu czasu traci swą zależność od artysty, stając się bytem autonomicznym; relacja podmiotu i przedmiotu ustanowiona zostaje niejako à rebours. Konsekwencją takiego przewartościowania relacji tworzącego do wytwarzanego jest fakt, iż nie przemawia do współczesnego odbiorcy ani bohater historii, ani artysta; mówi do niego dzieło sztuki.

Odpowiedzią na ten szczególny rodzaj doznania estetycznego staje się napisanie dzieła przy wykorzystaniu formy gatunkowej, której genezy doszukiwać się należy właśnie w czasach starożytnych. George Sutherland Fraser, badając ody Keatsa, pisal, że „an ode is traditionally [...] a lyric that is exalted or enthusiastic in tone, and whether regular or not, elaborately designed" (Fraser 128). Pochwalny utwór opiewający w podniosłym tonie sztukę ma - w założeniu wynikającym z jego wyznaczników gatunkowych - unieśmiertelnić ją, podobnie jak ona unieśmiertelniła wydarzenia i postaci. Formułowane tak postulatywnie przez Norwida pytania o los wielkich postaci nie mogłyby znaleźć swego miejsca w utworze Keatsa ze względu na fakt, iż „ja” mówiące $w$ tym liryku swój stosunek do tradycji antycznej postrzega raczej jako możliwość odczytywania z „kroniki lasów” (w. 3) - jak określa urnę - historii ludzkich. O ile zatem Norwid w swych rozważaniach na temat sztuki stał zdecydowanie na stanowisku, które moglibyśmy określić jako antropocentryczne, o tyle Keats optuje za bezsprzecznym prymatem artefaktu nad jego twórcą. Co istotne, obu artystów łączy przy tym wspólny cel: kontemplacja doskonałości starożytnej sztuki oraz zdefiniowanie najważniejszych jej idei.

Wskazywanie powiązań analizowanych tutaj utworów z antycznymi koncepcjami sztuki i piękna warto uzupełnić o ustalenia dotyczące ustosunkowania się obu romantyków do teorii mimesis. Definicję tego pojęcia przyjmuję za Władysławem Tatarkiewiczem, który proponuje, by rozumieć je bądź jako nazwę czynności, bądź stosunek dzieła do wzoru (Tatarkiewicz 15). Marmur-biaty zdaje się podejmować tę kwestię jedynie w sposób marginalny. Podmiot mówiący, odtwarzając wizerunek starożytnej Grecji, kreuje go na wzór pięknej kobiety, której postać konotować może pewne wyobrażenia antycznej rzeźby (Wyka 29). Marmurowe ramiona i wygięta 
kibić współczesnej Grecji są niejako „rekonstrukcją” jej dawnego wizerunku. Norwid, według którego „najpowszechniej przyjęte rozumienie sztuki jako naśladowania natury jest może rozumieniem jej najniższym" (Norwid 339), starał się przetwarzać tradycję, wzbogacając ją o nowe elementy. O wiele wyraźniej do koncepcji mimesis nawiązuje opiewana przez Keatsa urna przedstawiająca (odtwarzająca) dawne dzieje i bohaterów, uobecniająca je. Jak twierdzi Helen Vendler, "the art of the urn-sculptor is [...] mimetic, but it is mimetic in a philosophical way, not a photographic one; it does not catch some lost historical model, but rather it chooses evocative human postures" (Vendler 133). Wydarzenia prezentowane przez dzieło sztuki zostają przetworzone nie tylko przez pióro i język poetycki samego autora utworu, ale także przez jego imaginację oraz zdolności percepcyjne.

Omówione tu sposoby reinterpretacji antycznego rozumienia piękna ujawnią się także przy wskazaniu stosunku obu poetów do koncepcji Johanna Joachima Winckelmanna określanego przez Marię Kalinowską mianem odkrywcy „dla współczesnego świata zagubionego piękna greckiej sztuki” (Kalinowska 1994: 113). Zwracał on między innymi uwagę na zespolenie w cywilizacji antycznej natury z kulturą, wskazując jednocześnie na dwie najważniejsze jej cechy: szlachetną prostotę i cichą wielkość. W kraju Homera widział miejsce, gdzie panuje idealna harmonia będąca wyrazem uniwersalnego, ponadczasowego piękna. Marmur-biaty uznać można za utwór podejmujący pewne cechy Winckelmannowskiego myślenia. Norwid, podobnie jak autor Geschichte der Kunst des Altertums, występował przeciwko pedanterii historyków sztuki: „wyżej stawiał wrażliwość estetyczną i wyrobienie smaku niż wiedzę o sztuce, obawiał się rutyny badaczy zajmujących się jedynie stroną techniczną dzieła sztuki" (Szmydtowa 645). Na kartach rozprawy Krytyka i artyści wskazywał na "dziwnie chrześcijańskie" stanowisko Winckelmanna postulującego, iż recepcji sztuki towarzyszyć musi ", atmosfera połączająca piersi widzów z tym, co widzieć przychodzą, a co z sztukmistrza piersi wyszło" (Cypriana Norwida myśli... 1960: 28). Marmur-biały jest utworem, w którym możemy doszukać się realizacji powyższego założenia. Przynosi on bowiem nie tylko zachwyt nad greckim pięknem, ale także sformułowania ewokujące konieczność podjęcia przez współczesnego odbiorcę refleksji nad przemijalnością artysty, sztuki i klasycznego ładu.

Myśl tę rozwija również Oda o urnie greckiej, będąca wyrazem zachwytu nad wiecznym, niezwykle wymownym i angażującym wszystkie zmysły pięknem. W ujęciu Vendler Keatsowska urna ,is an experiment in thinking about art in terms of pure, «artificial» representational visuality extended in space" (Vendler 116). Badaczka wskazuje, że grecka sztuka, z jaką mogą obcować współcześni odbiorcy, jest tylko reprezentacją świata, do którego dostęp zamknął im już upływający czas. Myślenie autora Endymiona o starożytnym pięknie traktować więc można w istocie jako kontemplacje pewnej ponadczasowej idei tej kategorii estetycznej utrwalonej w zachwycającym kształcie greckiej urny. 


\section{Adresat i nadawca}

Omawiane w niniejszym szkicu liryki Norwida oraz Keatsa odczytywać można jako swoiste zaproszenie do dialogu, kierowane pod adresem antycznej kultury. Wskazują na to formy obu utworów i pojawiające się w nich liczne apostrofy. Zastanawiając się, kim jest osoba stawiająca w wierszu polskiego twórcy pytania „Grecji wdzięcznej”, należy wziąć pod uwagę kilka ewentualności. Pierwsza z nich mówiłaby, iż "ja” liryczne Marmuru-białego utożsamiać można z poetą, artystą wrażliwym na antyczne piękno, umiejącym wyciągnąć wnioski z historii oraz - co równie ważne - potrafiącym na ich podstawie przewidzieć dalszy rozwój dziejów ludzkości. Tezę tę poniekąd potwierdzają sformułowania samego Norwida, w świetle których prawdziwego twórcę cechować ma „wielka sztuki znajomość, doskonałość rysunku i starożytnych mistrzów” (Norwid 368). Założywszy arbitralność powyższych warunków, Norwidowski artysta, wspominając o losie ojczyzny Homera, ma prawo nazwać się twórcą $w$ dwojakim tego słowa znaczeniu. $Z$ jednej strony opisuje zachwycające go antyczne ruiny, z drugiej zaś - stawia marmurowy pomnik pięknu starożytnej Grecji, personifikując je i kształtując niczym postać kobiecą.

Kolejna z możliwości interpretacyjnych każe widzieć w podmiocie mówiącym obraz wspomnianego w wierszu [Klaskaniem mając obrzękłe prawice] „późnego wnuka" poczuwającego się w obowiązku do podjęcia refleksji nad tym, do czego doprowadziła obojętność "pokolenia ojców” względem antycznego piękna. Jego namysł nad zniszczonym dziedzictwem cywilizacji staje się $w$ tym ujęciu jednocześnie oskarżeniem wysuwanym nie tylko pod adresem starożytnych, ale także późniejszych pokoleń.

Podmiot mówiący można w końcu utożsamić z postacią zakochanego Norwida adorującego pod postacią marmurowej piękności Marię Kalergis. Ukochaną autora Promethidiona powszechnie nazywano „białą damą" (la dame blanche), w czym biografowie poety każą widzieć aluzję do jej jasnej karnacji (Sudolski 88). Warto zatem zastanowić się nad sensownością porównania „ja” lirycznego do Pigmaliona rzeźbiącego w materii słowa marmurowy posąg wdzięcznej, pięknej, acz milczącej i niewzruszonej Grecji-Galatei. Inspiracją dla działań „rzemieślnika” staje się chęć kontemplacji idei doskonałości, pragnienie admirowania niematerialnego pomnika piękna samego w sobie, które ożywa bądź raczej zostaje wskrzeszone przez artystę do literackiego życia. Kontekst ów wywołuje niewątpliwie pewne asocjacje z poezją parnasistów, gdyż w ich twórczości motyw podziwianej rzeźby zajmował także istotne miejsce.

Jednym z najciekawszych - jak sądzę - problemów, który do dzisiaj nie został jednoznacznie rozstrzygnięty, jest kwestia adresatki liryku. Na kartach licznych rozpraw i szkiców najwybitniejszych znawców przedmiotu pojawiają się odmienne głosy. Sudolski postuluje, by Marmur-biały czy tać jako „typowo norwidowski utwór o podwójnym adresacie: Grecji i zespolonej z jej obrazem ukochanej kobiety, której 
białe ramiona, błękitne oczy i profil Minerwy sławi poeta" (Sudolski 135). Podobnego utożsamienia kraju Homera z Marią Kalergis ${ }^{6}$ dokonuje także Mieczysław Inglot (Inglot 16). Większą powściągliwość w tej kwestii wykazuje Szmydtowa, wspominając co prawda o „uosobionej Grecji” (Szmydtowa 671), jednak nie identyfikując jej z przyjaciółką Marii Trębickiej. Zdecydowanie polemiczny stosunek do takiego odczytywania Marmuru-białego cechuje Michała Głowińskiego, który zapytuje: „nie wiadomo np. dlaczego wizja uposągowanej Grecji (w wierszu Marmur-biały) miałaby być obrazem pani Kalergis; jak się zdaje, ta romantyczna grande dame bardziej niż Norwidowi zawróciła w głowie niektórym jego egzegetom" (Głowiński 80). Nakreślony krótko spór na temat odbiorcy niniejszego liryku, dzielący literaturoznawców na dwa obozy optujące bądź za utożsamieniem adresatki wiersza z postacią Marii Kalergis, bądź też za zdecydowanym odrzuceniem tej koncepcji, nie znajduje jednoznacznego rozstrzygnięcia. Argumenty obu stron, poparte zazwyczaj wyłącznie intuicją badaczy, wydają się - jak sądzę - niewystarczające dla jednoznacznego potwierdzenia, czy istnieje konieczność doszukiwania się powiązań między ukochaną Norwida a obrazem marmurowej Grecji. W dwóch początkowych strofoidach przyjmujących formę rozbudowanej apostrofy do "Grecji pięknej”, "Grecji wdzięcznej” mamy prawo jedynie domniemywać istnienia pewnych odpowiedniości pomiędzy wspomnianą krainą a bliżej nieokreśloną kobietą. Zwraca tutaj uwagę zastosowane przez poetę uosobienie ojczyzny Homera, która - w myśl Norwida - ma „ramiona z marmuru" i - co równie istotne - „serce..." (w. 2). Na tak wykreowany obraz Grecji podmiot mówiący spogląda z podziwem. Pojawiającą się w ostatniej części eksklamację „...Oh! Pani, / Błękitno-oka, z równym profilem Minerwy...” (w. 16, 17) uznać należy z jednej strony za wybuch uczuć poety zachwyconego urodą opisywanej postaci, z drugiej zaś - za wyraźny sygnał, by móc widzieć w obrazie Grecji adorowaną kobietę. Co istotne, zarówno w liryku Norwida, jak i w wierszu Keatsa podmiot liryczny swój zachwyt antycznym pięknem wyraża z pewnego dystansu, wynikającego z niemożności zbliżenia się do ideału.

Koncepcji podmiotu mówiącego w Odzie o urnie greckiej poświęcono już wiele rozpraw. Najczęściej brytyjscy literaturoznawcy skłaniają się ku odczytywaniu niniejszego liryku jako realizacji sformułowanej przez Keatsa teorii negative capability ${ }^{7}$ tłumaczonej przez Stanisława Barańczaka jako „zdolność do zanegowania samego

6 Marmur-biaty nie jest jedynym utworem Norwida, w którym - jak przekonują badacze - widzieć można utożsamienie postaci z dzieła literackiego z Marią Kalergis. Przykładowo, Zbigniew Czajkowski za porte parole ukochanej poety każe uznawać także Marię Harrys - główną bohaterkę Pierścienia Wielkiej Damy (Czajkowski 54).

7 Pojawiła się ona w liście do George’a i Thomasa Keatsów z dnia 21 grudnia 1817 roku. „I had not a dispute but a disquisition with Dilke, on various subjects; several things dovetailed in my mind, \& at once it struck me, what quality went to form a Man of Achievement especially in literature \& which Shakespeare possessed so enormously - I mean Negative Capability, that is when man is capable of being in uncertainties, Mysteries, doubts without any irritable reaching after fact \& reason" (Rollins 193-194). 
siebie", czyli umiejętność „doświadczenia realności bez narzucania jej cech osobowości artysty" (Keats 1997: 12) ${ }^{8}$. W swoich rozmyślaniach poświęconych pięknu antycznej urny ,ja" liryczne w sposób znamienny zdaje się otwierać swe wnętrze na wszelkie doznania docierające do niego z przedmiotu, który je zachwycił. Jest to jedna z możliwości, jak sugeruje Jack, "to escape from mundane reality and disturbing thoughts” (Jack 216). Tak pojmowane piękno oddziałuje na słuch („Heard melodies are sweet”; w. 11), wzrok („Of marble men and maidens operwrought"; w. 42), dociera do odbiorcy jako zapach (, a flowery tale more sweetly than our rhyme"; w. 4). Dostrzec tutaj można zaskakującą zbieżność z lirykiem Norwida, w którym również przedstawione zostają doznania zmysłowe, takie jak „szmer egejskich fal” (w. 4-5) czy „rytm klasku” (w. 6).

Najistotniejszym elementem w kreacji podmiotu mówiącego jest w Keatsowskim liryku - paradoksalnie - jego świadome ukrycie się na drugim planie, zejście ze sceny zdarzeń. Znamienne, iż w polskim przekładzie autorstwa Barańczaka raz tylko pojawia się czasownik $\mathrm{w}$ formie pierwszej osoby (co ciekawe, liczby mnogiej - "Gdy my, żywi, odejdziemy"; w. 47), podczas gdy oryginał w ogóle pomija tego typu konstrukcje („When old age shall this generation waste”; w: 46). Charakterystyka ,ja” lirycznego jest zatem możliwa jedynie przez pryzmat doznań estetycznych, jakie są mu dane. Na Norwidowskie, niezwykle ekspresyjne, "mów”, "rzeknij”, „zapisz” skierowane przez podmiot liryczny do podziwianego artefaktu nie ma miejsca w wierszu Keatsa, w którym piękno przemawia, nawet niepytane.

Sformułowanie pojawiające się $\mathrm{w}$ ostatniej strofie, będące przesłaniem urny, nawiązuje do Platońskiej koncepcji idei. Przekonanie, iż „beauty is truth, truth beauty" (w. 49), wskazuje na nierozerwalny związek istniejący pomiędzy pięknem a prawdą . Tym samym dostrzeżenie przez artystę wartości estetycznych wiązać się musi z poznaniem przez niego wartości etycznych. Poeta, opisując otaczającą go rzeczywistość w sposób niemalże obiektywny i dający sposobność pojęcia esencji rzeczy, nagradzany jest możnością dostrzeżenia prawdy tkwiącej w istocie dzieła. Myśl tę rozwija Keats w jednym ze swoich listów, gdzie notuje: „I am certain of nothing but the holiness of the Heart's affections and the truth of Imagination what the Imagination seizes as Beauty must be truth"10 (Keats 1971: 30). Koncepcja „ja" lirycznego z Ody o urnie greckiej jest w znacznej mierze podobna do podmiotu mówiącego w Marmurze-białym, cechującego się wrażliwością i zdolnością do refleksji przekraczającą umiejętności zwykłego człowieka.

8 Fragmenty wierszy Keatsa w języku polskim i angielskim podaję za tym właśnie wydaniem, w nawiasie zaznaczając numer wersu.

9 W twórczości Norwida, by przywołać chociażby Promethidiona, piękno i prawda zostają jeszcze uzupełnione o dobro.

10 Fragment listu do B. Baileya z 22 listopada 1817 r. 


\section{Dialog i milczenie}

Ustaleniu relacji zaistniałych między podmiotem mówiącym a odbiorcą przedstawionym w utworach Keatsa i Norwida winno towarzyszyć podjęcie refleksji nad problemem milczenia i dialogiczności, tak wyraźnie rysującym się w Marmurze-biatym oraz w Odzie o urnie greckiej. W obu lirykach zagadnienia te odgrywają kluczową rolę w sposobie prezentowania i ujmowania piękna. Milcząca wymowność artefaktu niejako implicite zakłada istnienie wspólnego kodu, nici porozumienia pomiędzy człowiekiem a sztuką, antykiem a kolejnymi epokami, tym, co ziemskie a tym, co transcendentne. Marian Śliwiński zauważa, że w takim ujęciu akt komunikacji artysty i kamiennego posągu jest próbą przekroczenia barier czasoprzestrzeni, w której żyje twórca. Wybierając, jak sugeruje badacz, ,język rzeźby", XIX-wieczny artysta przyznaje dziełu charakter absolutny, uniwersalny (Śliwiński 118).

Norwidowski liryk uznać można za szczególny rodzaj monologu, który - w definicji autora Promethidiona - ,jest rozmową [podkr. moje - E.Ż.H.] ze sobą albo z duchem rzeczy" (Norwid 232). Tworzący wiersz szereg pytań skierowanych do antycznej Grecji to wyraz zachęcenia jej - uosobionej idei piękna zaklętego w białym marmurze - do podjęcia dyskusji z podmiotem mówiącym. Jak pisze Łapiński, u Norwida

ów idealny partner włączony jest w samą budowę dzieła, tak jak włączony jest [...] jego rozmówca [...]. Bo autor kreuje nie tylko swój świat poetycki, powołuje ponadto do życia dwu uczestników tego świata, dla których i przez których owa rzeczywistość istnieje (Eapiński 38).

Warto wyznaczyć w tym miejscu płaszczyzny, na których ów dialog się realizuje. Jedną z nich może być próba nawiązania rozmowy pomiędzy istotą śmiertelną a tym, co "wiecznie żywe" - tradycją antyczną. Mimo że świadectwem istnienia starożytnej Hellady są jedynie gruzy, wciąż przemawia ona do człowieka "witanymi z radością" zwaliskami, na których wyrastają już tylko „łzawiejące fijołki drobne”. Romantyczna ruina, jak przekonuje Grażyna Królikiewicz, „prowadzi [...] do interpretacji estetycznej, jeśli widzieć w niej przedmiot stanowiący samoistne źródło przeżyć" (Królikiewicz 10). Rodząc skojarzenia z ideałem antycznego piękna, sama wzbudza u odbiorcy doznania estetyczne. W utworze Norwida doszukać się można zatem jeszcze jednego, równie ważnego rodzaju dialogu, tworzonego przez rozmowę wrażliwego na piękno twórcy z dziełem artystycznym. Jest to szczególny rodzaj kontaktu między człowiekiem kochającym a podziwianym przez niego obiektem („Błękitno-oka, z równym profilem Minerwy.../ - stąd to zwaliska twoje są, jak ty, nadobne"; w. 16-18).

Równie silnie, acz niejednoznacznie, problem dialogiczności podejmuje Oda o urnie greckiej, gdzie także istotną rolę odgrywają pytania stawiane przez pod- 
miot mówiący przedmiotowi będącemu dla patrzącego źródłem doznań estetycznych. Nawiązanie dialogu między człowiekiem a dziełem sztuki staje się możliwe w chwili zaistnienia pomiędzy obiema stronami tego samego kodu oraz wspólnego systemu znaków. W utworze Keatsa jest nim niewątpliwie język sztuki. Namalowane na urnie gałęzie przemawiają do poety swą szczęśliwością, melodie - słodyczą brzmienia, wichry - zimnem. Pojawiające się $\mathrm{w}$ utworze synestezje $\mathrm{e}^{11}$ jednoznacznie wywołują konieczność uświadomienia sobie wyjątkowości sposobu prowadzenia dialogu między człowiekiem a sztuką. Poetę uznać można także za pośrednika łączącego artefakt z rzeczywistością zewnętrzną. On bowiem, mając (jako jednostka wybrana) dostęp do owej prawdy tak wyraźnie eksponowanej w ostatnim wersie utworu, posiada niezbędne predyspozycje, by w sposób najwłaściwszy percypować niemy głos greckiej urny.

Już samo nazwanie tytułowej bohaterki wiersza „, still unravished bride of quietness" (w. 1) wydaje się niezwykle sugestywne. Mowa tu niewątpliwie o milczeniu jedynie pozornym. W pierwszej strofie wiersza następuje bowiem niejako wejście podmiotu lirycznego w świat, którego wizerunek zdobi grecką urnę, wkroczenie do rzeczywistości sztuki absolutnej, idealnej, oddzielonej od ludzkiego świata granicą czasu, przestrzeni i milczenia. $W$ obliczu tak rozumianej transgresji doświadczanej przez „ja” liryczne bezgłośność utożsamiona zostaje ze słodką melodią (w. 11). Doznanie to nie dociera do ludzkich uszu, a do duszy (w. 14). Keatsowskiemu milczeniu trzeba przypisać atrybut niezwykłej wymowności. Prawdziwa sztuka przemawia bowiem do odbiorcy, oddziałując na jego wyobraźnię i jednocześnie dając mu możliwość wejścia do swego wnętrza, dotarcia do swej istoty.

Norwidowska koncepcja milczenia, uznająca je za jedną z części mowy, zakłada, że ono „daleko więcej od mówienia wyrazić może” (Norwid 331). Stąd zatem adresatka Marmuru-białego, podobnie jak Keatsowska urna, nie podejmuje bezpośredniej rozmowy z poetą. W braku odpowiedzi błękitnookiej można z jednej strony doszukiwać się potwierdzenia słuszności Norwidowskich oskarżeń kierowanych pod jej adresem, z drugiej zaś faktu, iż antyczna Grecja przemawia do wrażliwej duszy artysty w sposób niezwerbalizowany obrazem "fijołków drobnych". Kalinowska wyraźnie podkreśla

wciąż obecny [...] w twórczości Norwida dramat słów wypowiedzianych i oczekujących odpowiedzi, a napotykających milczenie, niedopełnionych przez drugiego człowieka, i w tak pustoszący sposób powracających ku podmiotowi wypowiadającemu (Kalinowska 1989: 240).

11 Jak zauważa Halkiewicz-Sojak przy okazji interpretacji twórczości Norwida, „jednym z rezultatów «milczenia» rozumianego jako stan kontemplacji bywa zlewanie się wrażeń dostarczanych przez różne zmysły i osiągana dzięki temu harmonia między człowiekiem «zewnętrznym» a «wewnętrznym»" (Halkiewicz-Sojak 156). 
Wielokrotnie stosowane przez autora Promethidiona aposjopezy oraz myślniki uznać można za graficzny wyraz istnienia płaszczyzny przemilczeń na kilku poziomach. Jedna z nich odnosi się do starożytnej Hellady, druga zaś do samego poety, który urywając swą wypowiedź, sugeruje czytelnikowi konieczność podjęcia głębszej refleksji nad danym fragmentem wiersza, poświęcenia mu większej uwagi. Milczenie oddawane przez znaki diakrytyczne staje się zatem postulatywną formą kontemplacji sztuki, koniecznością podjęcia nad nią głębszego namysłu przez przedstawiciela kolejnych pokoleń, spadkobiercę tradycji przodków.

\section{Czas}

Jak twierdzi Inglot, „wyobraźnię poetycką Norwida cechowało uniwersalne podejście do procesu dziejowego. Był to jednak zawsze proces tworzony przez wielkie jednostki [...] pozornie przegrywające w życiu, ale triumfujące po śmierci" (Inglot 22). Pierwsza lektura Marmuru-biatego może sugerować interpretację wręcz odwrotną do cytowanych wyżej słów literaturoznawcy. Wymienione w wierszu nazwiska artystów i wielkich wojowników, zdaniem "ja" lirycznego, zacierają się w pamięci odbiorców, gdzie swe miejsce znajdują tylko wspomnienia o ludzkich dziełach bądź dokonaniach. Taki sposób lektury jest jednak niepełny. Już tytuł wiersza, gdzie pojawia się nazwa skały, z której wykonywane są monumenty, sugerować może, iż postaci antycznych sztukmistrzów nie przeminęły. Pomnik ich wielkości stawia bowiem w płaszczyźnie metatekstowej XIX-wieczny artysta. Reprezentatywne dla antyku nazwiska wciąż pozostają żywe dzięki wyrzeźbieniu ich przez autora Promethidiona w białym marmurze literatury.

Norwidowska koncepcja czasu silnie związana jest z zagadnieniem przeżycia estetycznego rodzącego się w człowieku stojącym nad "nadobnymi zwaliskami” antycznej Grecji. Na tych właśnie gruzach zakwitają rokrocznie operlone rosą fiołki, których symbolika wskazywać może na odradzanie się nowego życia na fundamencie starożytnych ruin. Zachwycająca Grecja upadła, by ustąpić miejsca przyciągającym wzrok przechodnia kwiatom. Takie ujęcie czasu, będącego siłą pod pewnym względem destrukcyjną, jednocześnie nie wyklucza istnienia ewolucji, w efekcie której jedne formy piękna ustępują miejsca innym bądź w nie przechodzą, stając się źródłem doznań estetycznych dla kolejnych pokoleń. W obrazie tym doszukać się można zajmującej wielokroć Norwida opozycji cywilizacji i natury. Podczas gdy wypracowana dłońmi kolejnych pokoleń kultura upada, przyroda odradza się każdego roku. Owo zderzenie dwóch sposobów przemijania wiąże się u Norwida z koncepcją ponadczasowości prawdziwego piękna, które - czy to w postaci „zwalisk nadobnych", czy operlonych rosą fiołków - trwa przez wieki.

Koncepcja czasu w Odzie o urnie greckiej jest w znacznej mierze paralelna w stosunku do sposobu ujęcia tej problematyki w Marmurze-biatym. Sztuka w odczuciu 
Keatsa unieśmiertelnia piękno. Urna, będąca, jak pisze Szturc, „świadkiem i skarbnicą dawno pogrzebanych kultur" oraz "poetyckim nawiązaniem do grobu” (Szturc 213), funkcjonuje w kulturze jako naczynie do przechowywania tego, w co zamieniło się po śmierci ludzkie ciało. Jest ona dziełem sztuki, wytworem rąk artystów zawierającym w sobie prochy człowieka, ale także zmaterializowaną formą związanych z nim wspomnień chronionych przed działaniem czasu. Prymarną funkcją Keatsowskiej urny nie jest jednak unieśmiertelnienie wypełniających ją popiołów. Jej kontemplacja wiąże się bowiem ściśle z podziwem dla zamkniętej w niej hellenistycznej idei piękna i dobra.

W utworze Keatsa, podobnie jak u Norwida, silnie wyeksponowane zostało trwanie, statyczność podziwianego przedmiotu. Wyłącznie w świecie sztuki „songs are forever new, love is forever young [...], beauty is truth" (Vendler 61). Jakkolwiek owa statyka najpełniej przejawia się w Norwidowskiej koncepcji ruin, także u Keatsa została dosadnie wyeksponowana. Angielski romantyk zestawił ją z dynamiką przejawiającą się $\mathrm{w}$ zachowaniu namalowanych na urnie postaci, które, działając, jednocześnie trwają niezmienione. Spostrzeżenie to prowadzić może do porównania nieprzemijalności sztuki z kruchością ludzkiego losu. Podobnie jak u Norwida, Keatsowski podmiot mówiący ma świadomość, że opisywana przez niego urna nie straci wiecznego życia, „When old age shall this generation waste” (w. 46). W tym ujęciu cywilizacja oraz kultura trwają zdecydowanie dłużej niż natura i ziemska egzystencja. Ciekawe wnioski nasuwają się po zestawieniu namalowanych na urnie "gałęzi, z których nie uleci / Liści, które $\mathrm{w}$ wieczności wiosny niewzruszenie wierzą" (w. 21, 22) (ang. „Ah, happy, happy boughs! that cannot shed/ Your leaves, nor ever bid the Spring adieu"; w. 21, 22) z obrazem Norwidowskich "fijołków" odradzających się co roku na gruzach antycznej Grecji. Zauważmy, że wiecznie trwająca wiosna ukazana w wierszu Keatsa jest tak naprawdę zależna od istnienia artefaktu, który tę właśnie nieśmiertelność jej zapewnia. Piękno Norwidowskich kwiatów, mimo że każdego roku zamiera, $\mathrm{w}$ istocie co roku odradza się na nowo.

\section{Ekfraza}

W Marmurze-biatym oraz Odzie o urnie greckiej obecne są elementy świadczące o możliwości zaklasyfikowania wymienionych utworów jako liryków wykazujących cechy typowe dla ekfrazy. Zgodnie z ustaleniami Michała Pawła Markowskiego, termin, który tutaj przywołuję, ma kluczowe znaczenie „dla badań nad obrazującymi, opisowymi, czyli najogólniej: wizualizującymi możliwościami języka" (Markowski 229). Romantyczni poeci, tworząc, w świetle teorii Cycerona, "przedstawienie tak żywe, że ma się wrażenie, iż widzi się to, co się tylko słyszy" (Markowski 229), uwiecznili w swych wierszach dzieła plastyczne, realizując tym samym romantyczny postulat korespondencji sztuk. 
Autor Promethidiona jednym z konstytutywnych założeń swej działalności literackiej uczynił stwierdzenie: „W każdej ze sztuk niechże wszystkie lśnią - prócz onej, przez którą utwór będzie wyrażony" (Norwid 76, podkr. C.K.N.). Realizacją tego postulatu jest wiersz Marmur-biaty, będący specyficznym sposobem nakreślenia poetyckim językiem pomnika (bądź rzeźby) antycznej Grecji. Teoria ekfrazy, opierająca się na unaoczniającej mocy słowa (Markowski 230), zakłada jednocześnie postulat istnienia wiernej, językowej reprezentacji dzieła plastycznego. Między wymienionymi tutaj dziedzinami sztuki znaleźć się musi zatem pewna płaszczyzna wspólna, wspólny kod, jakim jest idea piękna tkwiącego w samej rzeczy, którego percypowanie zależy nie tyle od przedmiotu, do jakiego się odnosi, a raczej od wrażliwości odbiorcy. Opisywana przez Norwida marmurowa postać zachwyca swą urodą i wdziękiem. Podmiot mówiący wiersza oddaje przymioty opisywanej Pani błękitnookiej nie tylko w bezpośrednich, językowych zwrotach wartościujących (,Grecjo piękna!”, ,'Wdzięczna Grecjo”), ale także przez szczegółową deskrypcję kobiecej postaci. Ubierając swą wypowiedź w formę rozbudowanej apostrofy ${ }^{12}$, ukazuje czytelnikowi obraz istoty o marmurowych ramionach, wygiętej kibici, nogach stąpających z lekkością bogom podobną, błękitnych oczach i profilu Minerwy. W efekcie realizuje Horacjański postulat ut pictura poesis. Słowo poetyckie, a zatem i język, jest ponadczasowym łącznikiem między wizerunkiem marmurowej „całości” a "nadobnymi zwaliskami”, spełniając tym samym zasadniczy dla ekfrazy postulat przedstawiania w literackim dyskursie ewolucji opisywanego zjawiska.

Oda o urnie greckiej to przykład zdecydowanie bardziej reprezentatywny, jeśli chodzi o realizację założeń uznawanych $\mathrm{w}$ teorii ekfrazy za fundamentalne. Wiersz Keatsa, będąc w istocie opisem dzieła sztuki, ma unaocznić (evidentia) i przybliżyć (enargeia) odbiorcy przedmiot podziwiany przez , ja” liryczne. „Uobecnienie w dyskursie tego, co pozajęzykowe" (Markowski 229) jest możliwe nie tylko dzięki stosowaniu przez autora Endymiona szeregu środków artystycznych służących uplastycznieniu opisu, ale także przez realizację wspomnianej wcześniej teorii negative capability, redukującej istotowość patrzącego do czystej, receptywnej świadomości. O ile zatem umysł artysty-obserwatora staje się sui generis pośrednikiem pomiędzy sztuką a odbiorcą rzeczywistym, o tyle za rodzaj medium uznać należy samą urnę. Marshall McLuhan wprowadził do XX-wiecznego dyskursu naukowego twierdzenie "the medium is the message" (McLuhan 212), które - jak sądzę - doskonale daje się zastosować przy badaniu ,języka" dzieła sztuki przedstawionego przez twórcę Hyperiona. Zauważmy, iż Keatsowskie przedstawienie urny nie ogniskuje się wokół nakreślenia jej kształtu czy wielkości - słowem - formy. Romantycznego poetę interesuje jej „treść”, czyli obrazy, którymi przemawia ona do obserwatora.

12 Zgodnie z ustaleniami Markowskiego, narratywizacja i apostrofa są najlepszymi sposobami wprowadzenia „efektu wizualizacji” - konstytutywnego składnika ekfrazy. 
Wyobraźnia odbiorcy, poruszona tak plastycznym przedstawieniem, w efekcie napełniona zostaje szeregiem niezwykle szczegółowo uchwyconych obrazów. Podobnie jak u Norwida, zadaniem twórczego umysłu jest teraz złożenie z posiadanych elementów pewnej wizualnej całości, co możliwe staje się w myśl zasady pars pro toto. Tak wiernie odtworzone detale pozwalają na skonstruowanie całościowej wizji kontemplowanego przedmiotu. Wiąże się z tym - jak przypuszczam - szczególny sposób patrzenia na koncepcję mimesis. Sztuka, przywołując dawne piękno, przetwarza je i ujmuje w sposób sobie właściwy. Kolejny etap tego procesu dokonuje się już w umyśle patrzącego. W obu utworach mamy do czynienia z podwójną mediacją $\mathrm{w}$ procesie postrzegania dzieła sztuki. Stosowanie ekfrazy $\mathrm{w}$ tym przekazie można uznać za zabieg używany przez romantycznych poetów $\mathrm{w}$ celu zniwelowania bądź choćby zmniejszenia dystansu pomiędzy czytelnikiem a starożytnym ideałem piękna, które ma wywołać w człowieku doznanie estetyczne.

\section{Słowo podsumowania}

Piękno w ujęciu romantyków to idea, do której poznania dąży wrażliwy umysł artysty. Jest ona trwała i niezmienna w czasie, jednakowo obecna w ruinach, rzeźbach i urnach, odbierana zmysłowo i rozumowo. Do pełnego i ponownego uobecnienia owa, jak ją określa Samuel Taylor Coleridge, muta poesis ${ }^{13}$ (Coleridge 80) potrzebuje głosu umiejącego nawiązać dialog nie tylko z nią samą, ale także ze światem zewnętrznym i z ludźmi w nim żyjącymi, którzy niejednokrotnie nie potrafią zobaczyć wielkości w antycznych zwaliskach czy detalach przedstawionych na antycznych urnach. Dostrzeganie piękna określonej całości musi wiązać się - o czym wspominał Norwid - z odnajdywaniem go w tworzących je elementach i vice versa. Percypowanie antycznego świata zgodnie z zasadami pars pro toto (Norwid) oraz totum pro parte (Keats) wydaje się sposobem słusznym i w pełni uzasadnionym, gdyż jako jedyne daje możliwość odtworzenia i dotarcia do tego, co jawi się dzisiaj wyłącznie jako ślad, trop, znak odwołujący do niegdysiejszego istnienia przedmiotu, idei, cywilizacji.

Każdy z analizowanych wierszy $\mathrm{w}$ sposób nieco odmienny definiuje pojęcie piękna. O ile Norwid rozumie je jako wypracowany i ukształtowany przez człowieka milczący ideał, którego percepcja zależy wyłącznie od wrażliwości odbiorcy, o tyle definicja Keatsa opiera się na przekonaniu o istnieniu swoistego języka sztuki, przez który wyraża ona ideę piękna i prawdy. Ludzka percepcja uwarunkowana jest głównie otwartością zmysłów, które winny dostrzec $w$ przedstawionych na urnie postaciach i wydarzeniach dynamikę, usłyszeć ich dźwięki, zobaczyć dzieje i przemiany odmalowanych zjawisk w pełnej rozciągłości czasowo-przestrzennej.

13 Coleridge sformułowanie to zanotował w szkicu O poezji czyli sztuce. 
Ambiwalencja postaw twórców pierwszej połowy XIX wieku w stosunku do tradycji antycznej ma jedno ze swych źródeł właśnie w rozumieniu przez romantyków starożytnej sztuki. Wiara w możliwość mimetycznego przedstawienia świata ${ }^{14}$ za pomocą dzieła artystycznego, w którym zachowane zostaną wszelkie proporcje, niejednokrotnie spotykała się z sprzeciwem romantycznych umysłów ceniących w działalności rzeźbiarzy, malarzy i literatów ich nowatorstwo, inwencję oraz twórcze natchnienie. Nie znaczy to jednak, że był to sprzeciw całkowity. Starożytność uznać trzeba bowiem za okres już zakończony, podsumowany, który winien być dla późniejszych pokoleń - zatem właśnie i dla owej generacji wnuków - czasem antycypującym przyszłe losy świata, świadectwem pewnych nieprzemijających prawd. Za jedną z nich można uznać prawdę wyłaniającą się z wiersza Norwida o odrzuceniu artysty. Przez wiele lat zarówno autor Promethidiona, jak i twórca Endymiona musieli borykać się z tym problemem. Współczesna ich recepcja pokazuje jednak, że na gruzach ówczesnych polemik krytycznych wyrosły w końcu kwitnące po dziś dzień „fijołki” docenienia i uznania.

\section{BIBLIOGRAFIA}

\section{Literatura podmiotu}

Keats, John. 33 wiersze. Wybór, przekład, wstęp i opracowanie Stanisław Barańczak. Kraków: Znak, 1997.

Norwid, Cyprian Kamil. Pisma wszystkie. Zebrał, tekst ustalił, wstępem i uwagami krytycznymi opatrzył J.W. Gomulicki. T. 6. Warszawa: PIW, 1971.

\section{Literatura przedmiotu}

Coleridge, Samuel Taylor. „O poezji czyli sztuce”. Manifesty romantyzmu 1790-1830. Anglia, Niemcy, Francja. Wybór tekstów i opracowanie A. Kowalczykowa. Warszawa: Państwowe Wydawnictwo Naukowe, 1975. S. 78-88.

Cypriana Norwida myśli o sztuce i literaturze. Wyboru dokonał, wstępem i objaśnieniami opatrzył M. Jastrun. Warszawa: Czytelnik, 1960.

Fraser, George Sutherland, red. J. Keats. Odes. A Casebook. London: Macmillan Press LTD, 1971.

Głowiński, Michał. „Norwida wiersze-przypowieści”. Cyprian Norwid w 150-lecie urodzin. Materiaty konferencji naukowej 23-25 września 1971. Red. M. Żmigrodzka. Warszawa: PIW, 1973. S. 72-109.

Halkiewicz-Sojak, Grażyna. Wobec tajemnicy i prawdy. O Norwidowskich obrazach "całości”. Toruń: Wydawnictwo Uniwersytetu Mikołaja Kopernika, 1998.

Inglot, Mieczysław. Cyprian Norwid. Warszawa: WSiP, 1991.

$14 \mathrm{O}$ zagadnieniu tym pisał Coleridge, mówiąc, iż w romantycznym ujęciu mimesis musi zawierać w sobie elementy podobieństwa i niepodobieństwa, tożsamości i różnicy pomiędzy elementem naśladowanym i naśladującym. 
Jack, Ian. Keats and the Mirror of Art. Oxford: The Clarendon Press, 1967.

Kalinowska, Maria. Grecja romantyków. Studia nad obrazem Grecji w literaturze romantycznej. Toruń: Uniwersytet Mikołaja Kopernika, 1994.

Kalinowska, Maria. Mowa i milczenie. Romantyczne antynomie samotności. Warszawa: PIW, 1989.

Królikiewicz, Grażyna. Terytorium ruin. Ruina jako obraz i temat romantyczny. Kraków: Universitas, 1993. Łapiński, Zbigniew. Norwid. Kraków: Znak, 1971.

Markowski, Michał Paweł. „Ekphrasis. Uwagi bibliograficzne z dołączeniem krótkiego komentarza”. Pamiętnik Literacki 2 (1999). S. 228-236.

McLuhan, Marshall. Wybór tekstów. Red. E. McLuhan, F. Zingrone. Przeł. Ewa Różalska, Jacek M. Stokłosa. Poznań: Zysk i S-ka, 1995.

Melbechowska-Luty, Aleksandra. Sztukmistrz. Twórczość artystyczna i myśl o sztuce Cypriana Norwida. Warszawa: Neriton, 2001.

Rollins, Hyder Edward, red. The Letters of John Keats 1814-1821. Cambridge: Cambridge University Press, 1958.

Sławińska, Irena. „Kropla czasu w teatrze Norwida”. Cyprian Norwid w 150-lecie urodzin. Materiały konferencji naukowej 23-25 września 1971. Red. M. Żmigrodzka. Warszawa: PIW, 1973. S. 39-52.

Stefanowska, Zofia. „Norwidowski romantyzm”. Pamiętnik Literacki 4 (1968). S. 3-23.

Sudolski, Zbigniew. Norwid. Opowieść biograficzna. Warszawa: Ancher, 2003.

Szmydtowa, Zofia. W kręgu renesansu i romantyzmu. Studia porównawcze z literatury polskiej i obcej. Warszawa: PWN, 1979.

Szturc, Włodzimierz. Archeologia wyobraźni. Studia o Stowackim i Norwidzie. Kraków: Universitas, 2001.

Śliwiński, Marian. Norwid wobec antyczno-średniowiecznej tradycji uniwersalizmu europejskiego. Słupsk: WSP, 1992.

Tatarkiewicz, Władysław. Dzieje sześciu pojęć. Warszawa: PWN, 2006.

Vendler, Helen. The Odes of John Keats. Cambridge, Massachusetts and London: Belknap Press, 2003. 
